\title{
Mitigation of replant disease by mycorrhization in horticultural plants: A review
}

\author{
Li-Hui Lü̈ ${ }^{1,2}$ Qiang-Sheng $\mathrm{Wu}^{1,2,3 *}$ \\ ${ }^{1}$ College of Horticulture and Gardening, Yangtze University, Jingzhou, Hubei 434025, China \\ ${ }^{2}$ Institute of Root Biology, Yangtze University, Jingzhou, Hubei 434025, China \\ ${ }^{3}$ Department of Chemistry, Faculty of Science \\ University of Hradec Kralove, Hradec Kralove 50003, Czech Republic
}

\begin{abstract}
Replant disease refers to the result of monoculture-continuous repetitive planting of congeneric crops or coordinal crops in the same soil for many years. Such disease is recognized as one of the main limiting factors affecting plant growth and production of horticultural plants in many countries. As a result, replant disease in horticultural plants has become a world problem in agriculture and also a bottleneck restricting the sustainable development of agriculture. In general, replant disease results in unfavorable growth of horticultural plants, which is due to allelopathy, autotoxicity, and the imbalance of both soil physical-biochemical traits and soil microflora. An environmentally friendly contribution to this could be bio-controlled by beneficial microorganisms. Arbuscular mycorrhizal fungi, one of soil-inhabiting fungi, can form a symbiotic association in roots to mitigate the negative effects of replant disease in many horticultural plants. Moreover, arbuscular mycorrhizal fungi do not produce any environmental pollution in soils and are a potential biological control. The soil fungi could regulate better morphological, physiological and molecular levels in plants to respond to the disease. This review mainly outlined the current knowledge in mycorrhizal mitigation of replant disease in horticultural plants, which appears to be a promising strategy to improve growth of horticultural plants in replant soils.
\end{abstract}

Key words: arbuscular mycorrhizal fungi, glomalin, replant disease, root exudates, soil microflora

\section{INTRODUCTION}

Replant disease is a complex and compound disease that often occurs in horticultural crops. In general, replant disease refers to the monoculture-continuous repetitive planting of congeneric crops or coordinal crops in the same soil for many years (Utkhede, 2006; Bent et al., 2009), directly resulting in restraining plant development, decreasing resistance to diseases, decreasing yields of fruit, and ultimately worsening the soil environment (Rutto and Mizutani, 2006). Replant disease decreases plant growth as a result of heavily reduced photosynthesis by means of hindering chlorophyll synthesis, which results in leaf chlorina (yellowing) (Tewoldemedhin et al., 2011). Additionally, the degree of replant disease depends on the activity and extension of roots. Under monoculture conditions, plant root activity is decreased and thus absorption of nutrients is reduced. This is followed by the morphological symptoms such as less lateral roots, the entire root system becoming dark brown with the apex becoming black and root decay (Wang et al., 2007). The increase in pathogenic nematodes, soil-borne fungi (e.g.,

*Corresponding author. 
Fusarium and Venturia), bacteria, actinobacteria and oomycetes variously triggers soil replant disease (Benizri et al., 2005; Rumberger et al., 2007). Hence, replant disease in horticultural plants has become a world problem in agriculture, which strongly affects crop production (Yang et al., 2012).

Arbuscular mycorrhizal fungi (AMF) can form a symbiotic association with most terrestrial plants (Wu et al., 2013). Almost 3-20\% of plant carbohydrates can be absorbed by AMF for the growth and development of mycorrhizas. In return, AMF provide inorganic substances for the host plant (Ortas, 2012). Compared with non-AMF plants, mycorrhizal plants absorb more mineral nutrients by the mycorrhizal hyphal network into the roots (Baslam et al., 2011). Earlier studies showed that AMF play a key role in improving resistance to biotic and abiotic stresses, including replant disease. AMF effects on replant disease were found in peach, cucumber, grape, apple, tomato, pepper, strawberry and watermelon (Huang et al., 2003, Tab. 1). For example, Rutto and Mizutani (2005) revealed that the growth performance of peach (Prunus persica L. 'Ohatsumomo Batsch') under mycorrhization was better than under non-mycorrhization, providing a view in mitigation of replant disease. Wang et al. (2012) also observed that out of Glomus mosseae, $G$. intraradices and $G$. versiforme, cucumber (Cucumis sativus L. 'Jinyou No. 3') plants inoculated only with $G$. mosseae had greater biomass production under replanted conditions which implies that AMFmitigated replant disease is strongly dependent on the AMF species used. This review outlines the occurrence, reasons and mitigation paths of replant disease, and focuses on mycorrhizal functioning on the reduction of replant disease in horticultural plants.

\section{OCCURRENCE OF REPLANT DISEASE IN HORTICULTURAL PLANTS}

Replant disease is a worldwide problem, especially with the development of a large-scale intensive horticultural industry. In the pursuit of economic efficiency, there has been an increasing obstacle to continuous succession in horticultural production. In developed countries with large cultivated area, modern agricultural science and technology further intensified replant intensity. As a result, replant disease has become a bottleneck restricting the sustainable development of agriculture (Yu, 2011). The occurrence of replant disease involves many biological and non-biological factors inside the plant-soil-microbe complex and its environment (Ogweno and $\mathrm{Yu}, 2006$ ).

\section{Soil physical-chemical imbalances}

Soil nutrient imbalance may be the primary dimension for the replant problem in horticultural cultivation and management (Wilson et al., 2004; Xie and Li, 2008). In general, enhanced application of chemical fertilizers results in soil secondary salinization, nitrate accumulation, acidification, and soil sealing which are manifestations of nutrient imbalance (Gąstoł and Domagała-Świątkiewicz, 2015). Nitrate accumulation originates from long-term unreasonable fertilization, as well as irrational irrigation and cultivation that raises the underground water, and further increases soil secondary salinization (Yang et al., 2015). Also, acidic fertilizers containing nitrogen have a considerable negative effect on the soil porosity, volume density, relative water content and water retention capacity and thereby they accelerate the process of soil acidification (Ortas, 2012).

Soil enzymatic activity reflects the relative intensity of biochemical processes as well as the transformation of the substances in the soil (Wang et al., 2015; Sun et al., 2015a). Zhao et al. (2010) observed that the activity of soil proteinase, polyphenoloxidase, urease, and saccharase was substantially decreased in the rhizosphere with an increase of continuous cropping time. However, Zhang et al. (2015b) indicated that the activity of catalase and peroxidase in the soil was simultaneously increased with a decrease of soil polyphenoloxidase activity. Hence, replant disease of the same crop or even different crops brings about diverse effects in soil enzymes. There are also positive interactions between replant disease and soil enzymes. This is possibly due to the changes of the root micro-environment (Utkhede, 2006).

Soil aggregates are characterized by porosity and water stability in the soil and they coordinate the balance of solid, liquid and gas phases (Rillig et al., 2015). Huang et al. (2015) reported that long-term continuous monoculture decreased the soil aggregate percentage in $0-60 \mathrm{~cm}$ layer which is connected with a decrease of both soil organic carbon and glomalin-related soil protein (GRSP) (Wang et al., 2015). As a result, replant soil is characterized by a destroyed structure which strongly inhibits crop growth (Zou et al., 2014).

\section{Soil microflora imbalance}

Continuous monoculture conditions provide parasitic and breeding sites of pathogens in roots because the 


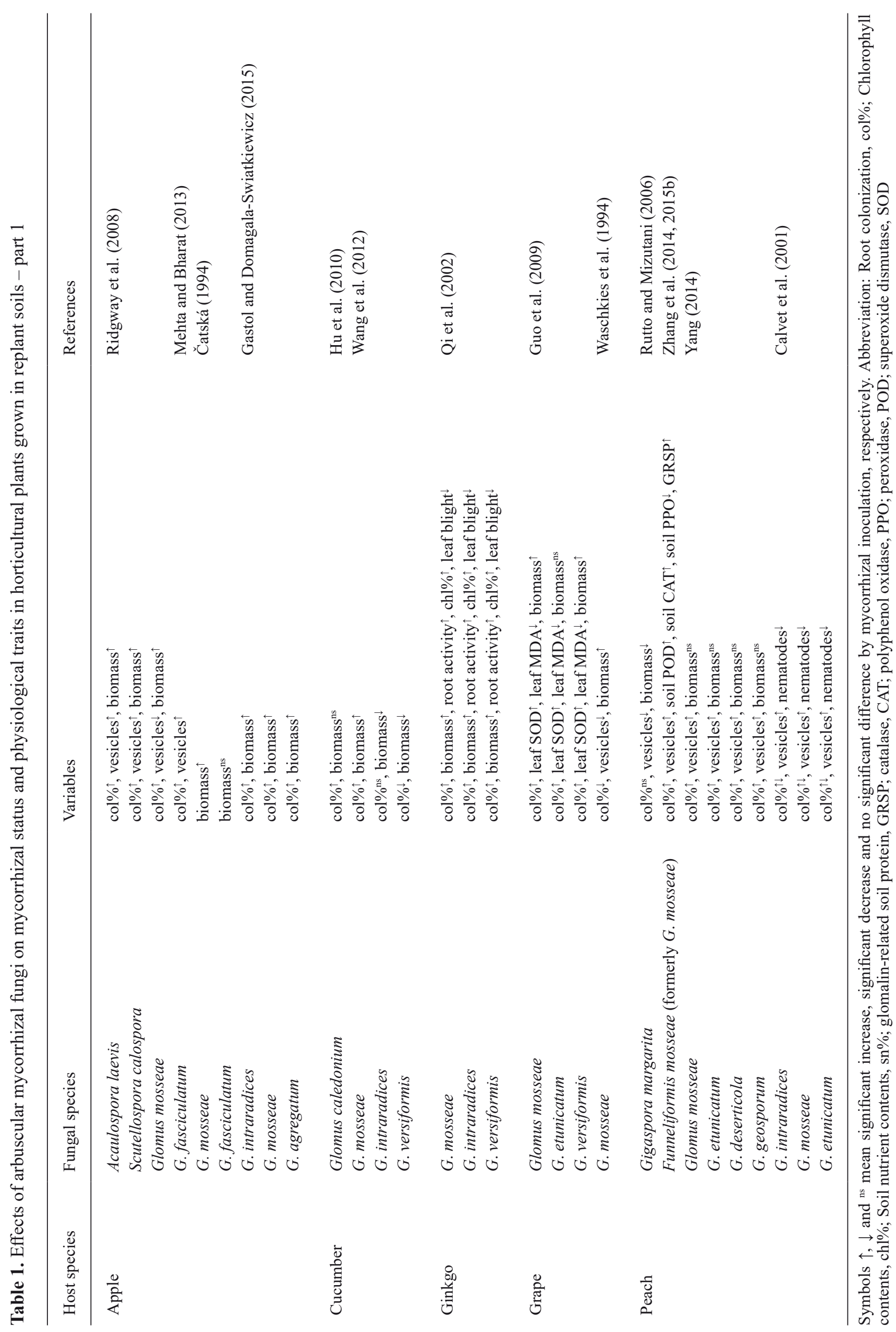




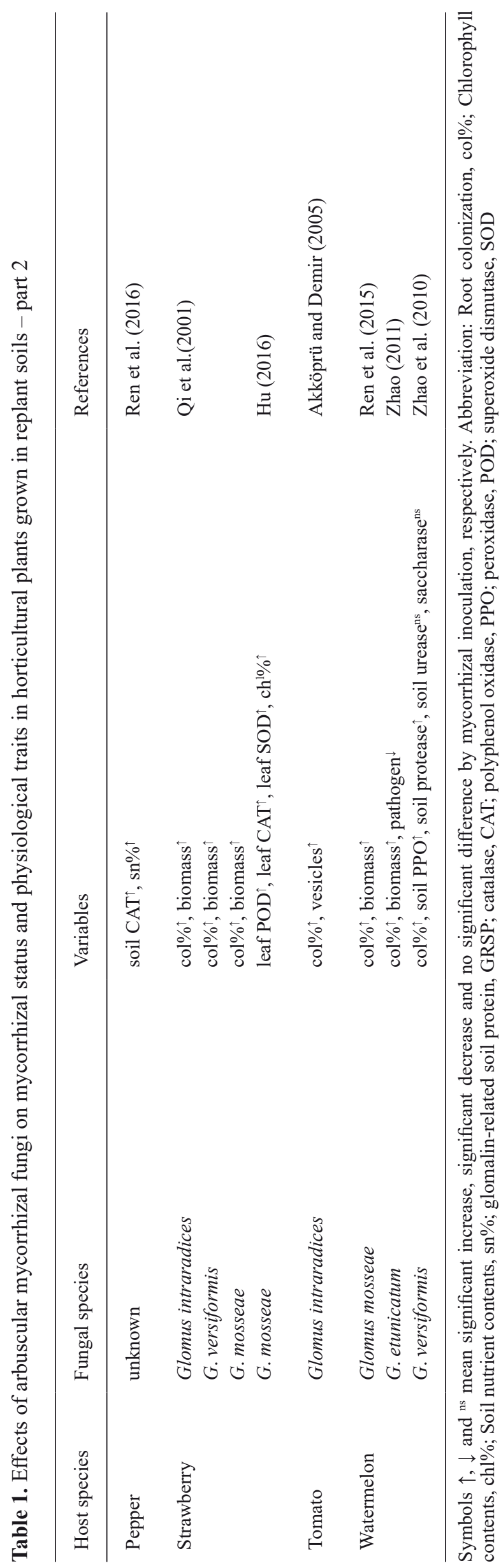

presence of the rhizosphere can produce hydrocyanic acid $(\mathrm{HCN})$ bacteria and actinomycetes resistance to cyanide and thus induces higher number of pathogens in roots and soil (Benizri et al., 2005). As reported by Li et al. (2016), nematode communities changed soil conditions in replanted strawberry (Fragaria ananassa Duch. 'Confidant'), and there was a competitive relationship between nematodes and plants for nutrient elements (Calvet et al., 2001). Replant soil accumulates more root exudates, which can promote faster reproduction of pathogenic nematodes (Wang et al., 1998).

In replant soils, the growth and fecundity of soil microflora are seriously disturbed and the dynamic balance of the microbial population density is negatively affected (Allison et al., 2007; Rumberger et al., 2007). In apple tree cultivation, soil microorganisms biodiversity particularly bacteria, fungi and nematodes were richer prominently in nonreplant soil than in replant soil (Utkhede, 2006). It was noted that long-term continuous monoculture results in both a decrease of soil microflora diversity and an increase of harmful microflora (Yao et al., 2006). Although AMF is present in replant soils, it has shown thin mycorrhizal formations in the root cortex and penetration into the central cylinder (Aldea, 1998). As stated by Sun et al. (2015b) soil microflora generally changed from "bacterial" high fertility in non-replant soil to "fungal" low fertility in replant soil.

\section{Allelopathy and autotoxicity}

Allelopathy is a kind of complex compounds that directly or indirectly impacts plant growth and development. These compounds are derived from root exudates or plant stubble (the remaining stumps of former crops), and microbial metabolism (Zhao et al., 2009). The effect of allelopathy in plants themselves is known as autotoxicity (Cheng and Cheng, 2016). Yu and Matsui (1994) isolated 11 phenolic substances from the root exudates of cucumber (Cucumis sativus L. 'Jinyan No. 4') and found that phenolic substances released by the roots could be accumulated to a certain extent in replanted cucumber and inhibit the growth of the next crop. In addition, alfalfa (Medicago sativa L. 'Vernal') plants secrete saponins and phenolic substances into the rhizosphere which seriously affect growth of latter crops (Hoagland et al., 2001; Chon, 2006).

Autotoxicity acts as a special form of allelopathy. Root exudates can stimulate the occurrence of pathogenic fungi, bacteria and nematodes in the 
rhizosphere or they can affect the germination of dormant spores of pathogens, to produce invasive structures for further infestation (Bais et al., 2006; Yin et al., 2016). On the basis of the root exudates of strawberry (Fragaria ananassa Duch. 'All Star'), it was concluded that root secretions triggered an increase in the electrolyte percentage and lipid peroxidation in root cells, resulting in more extensive accumulations of reactive oxygen species in roots (Zhen et al., 2004). Hence, replant management often inhibits plant growth and decreases the resistance to soil-borne diseases.

\section{MITIGATED PATHS OF REPLANT DISEASE}

\section{Soil amelioration and field management}

The reasonable use of fertilizers can effectively alleviate the occurrence of continuous cropping obstacles (Gąstoł and Domagała-Świątkiewicz, 2015). It was found that applying organic fertilizers such as pig manure and chicken manure into soil could improve the crop resistance to replant disease (Maskina, 1988; Wu et al., 2009). This is due to a more balanced nutrient ratio in organic fertilizer than in chemical fertilizer. In addition, introducing invertebrates such as earthworms (Feng, 2017) is efficient for mitigation of replanting problems.

Drip irrigation can dramatically increase the absorption of both water and nutrients and better soil aggregate structure, in comparison with traditional irrigation (Marouelli et al., 2013). Results of Wei et al. (2009) showed that drip irrigation under continuous cropping conditions markedly improved the soil ecological environment and enhanced resistance to replant disease. Currently, the technique of returning straw to farmland also improves the soil environment under continuous cropping conditions because straw can weaken the nitrification and denitrification reactions, reduce the accumulation of nitrates and nitrites and supply nutrients in the process of straw decomposition (Zhou et al., 2004).

\section{Optimization of cropping systems}

To mitigate continuous replant disease, reasonable crop rotations, intercropping and interplanting are often used in the field to increase the total amount of soil microbes as well as the bacterial/fungal ratio to alleviate continuous cropping disease (Mamolos and Kalburtji, 2001). Khan et al. (2014) intercropped maize (Zea mays L. 'Baiding No. 1') with peanut (Arachis hypogaea L. 'Yueyou No. 92'), and observed that intercropping significantly reduced the population of fungi, elevated the population of bacteria in maize rhizospheric soil, and increased soil enzymatic activity and carbon utilization with a decrease of nitrogen. Nanjappa et al. (2008) showed that in the system of peanut (Arachis hypogaea L.) and pepper (Capsicum annum L.) rotation, sunshine intensities produced different effects, and stronger light intensity was accompanied with greater yields of peanut and pepper. Earlier studies showed that the rotations of plant genotypes, distant relatives, soil water status, and "allelopathic crops" with the corresponding crops could reduce the hazard of replant disease (Alvey et al., 2003; Zhu and Fox, 2003). Furthermore, a similar conclusion was found in the rotation and intercropping of cassava (Manihot esculenta Crantz 'M. Col 113 Crantz') with legumes, such as cowpea (Vigna unguiculata L. 'Blackeye Walp'), peanut (Arachis hypogaea L. 'VA 98R') and mung bean (Vigna radiata L. 'Partov') (Sieverding and Leihner, 1984).

\section{Breeding of resistant varieties}

With the development of the molecular techniques in horticultural plants, genetic engineering and crop genetics and breeding technology have become important fields that enhance the tolerance to replant disease (Moose and Mumm, 2008). Lin (2010) analyzed the changes of proteomics in continuous cropping of heterophylla (Pseudostellaria heterophylla Miq. 'Zheshen No. 2 Pax') in replant versus non-replant soil. They found that the expression level of several proteins of leaves related to cell division and protein synthesis under replant soil was decreased which resulted in a decrease in the number of soil bacteria and bacterial species diversity. These results showed that breeding for high expression of relevant proteins (e.g., pathogenesis-related proteins) in plants is a major pathway for alleviation of replant disease. Duan et al. (2011) proposed that varieties resistant to replant disease should have characteristics of no self-toxicity, little autotoxicity, production of beneficial allelochemicals and root exudates. Wild horticultural plant species generally show better resistance than corresponding cultivars, because rhizospheric allelochemicals and effective microorganisms cause degeneration of pathogens as a result of antagonistic reactions. Thereby, under continuous cropping conditions, inclusion of wild ancestors into breeding programs is a possible pathway to enhance crop resistance to replant disease. 


\section{Application of chemical and biological preparations}

Pesticides are used to control fungal diseases, including carbendazim, chlorothalonil and mancozeb by seed dressing irrigation, foliar spraying and other ways (Guo et al., 2010). However, pesticides have lots of underlying problems in endurance, residues, and thus their application must be limited. Moreover, long-term use of soil disinfectants results in the accumulation of toxic substances, such as methyl bromide, pentachloronitrobenzene, and formalin (Yao et al., 2006). These soil disinfectants can also include chloropicrin and quintozene (Eayre et al., 2000; Sewell et al., 2010). In addition to disinfectants, high temperature, sunlight and steam are often used to eliminate soil pathogens in replant soils (Guo et al., 2010). In addition, fungicides often have detrimental effects on non-target beneficial microorganisms, including AMF (Comby et al., 2017).

Isolation of rhizospheric bacteria from relative wild species is superior in achieving anticipative effects in mitigating replant disease (Duan et al., 2011). To some extent, the introduction and activation of antagonistic bacteria against harmful fungi and nematodes is a good way to relieve replant disease. Both antagonistic bacteria and pathogens have similar adaptability in the same ecosystem. Antagonistic bacteria secrete antibiotic active substances to inhibit pathogenic microorganisms, and also promote the growth and reproduction of beneficial bacteria, which play an important role in the prevention of replant disease (Bryk and Mikicinski, 2009).

Additionally, grafting is often used to mitigate replant disease, because disease-resistant rootstocks in horticultural production possess better root development and greater capacity in both endogenous hormone production and antioxidant protected systems, collectively, leading to enhanced soil-borne disease resistance and alleviation of autotoxicity (Huang et al., 2016).

\section{UNDERLYING MECHANISMS OF AM FUNGI MITIGATING REPLANT DISEASE}

Mycorrhiza is a reciprocal symbiosis structure established between plant roots and AMF in the soil (Wu et al., 2008). In general, AMF can promote the absorption and utilization of water and mineral nutrient, improve plant growth, enhance the tolerance of abiotic stresses including drought, salinity, temperature stress, waterlogging and heavy metal pollution, together with biotic stresses e.g. fungal and bacterial disease, insects and nematodes (Nedeem et al., 2017). AMF can also efficiently ameliorate soil relevant parameters which improves water-stability aggregates (WSAs), soil organic carbon (SOC) and soil enzyme activities (Mehta and Bharat, 2013). AMF inoculation directly or indirectly affects the composition and content of root exudates, the soil microbes population and the growth and development of plants. As stated by Ortas et al. (2017), mycorrhizal application has been introduced into vegetables (e.g., onion, pepper, tomato, cucumber, and eggplant) and fruit trees (citrus, apple, grapevine and plum). Large-scale production of mycorrhizal fungi and their coating on seeds can provide a convenient approach to apply mycorrhiza into fields. Roy-Bolduc and Hijri (2012) proposed two approaches of using AMF in fields: native mycorrhizal inoculums selection and adopting cultural practices to enhance the indigenous AMF population.

Earlier study conducted by Čatská (1994) found that AMF application could replace soil chemical treatments in mitigating apple (Malus domestica Borkh 'Kids Orange Red') replant disease. Such effects were confirmed in many horticultural plants, as shown in Tab. 1. Although AMF can increase nutrition of the host plant, replant disease is not associated with mineral nutrition (Čatská, 1994). AMF-mitigated replant disease is a complex issue. Based on the analysis of previous studies, the underlying mechanisms regarding AMF mitigation of replant disease in horticultural plants are discussed as follows.

\section{Regulating the root and soil microflora balance}

In general, the root and soil microflora composition is different in replant versus non-replant soil (Čatská, 1994). Proliferation and numbers of fluorescent pseudomonades and total aerobic bacteria are much higher on roots in replant than in non-replant soil (Sheng and $\mathrm{Wu}, 2007$ ). Although replant soil strongly negatively affects root mycorrhizal colonization, such colonization still causes resistance of roots to pathogens in replant soil, because mycorrhizal fungi have shown resistance to soil pathogenic fungi, including Phytophtora parasitica, Fusarium oxysporum, Pythium ultimum, and to soil pathogenic bacteria, including Preudomonas syringae and P. solanacearum (Waschkies et al., 1994). As a result, mycorrhizal plants grown in replant soil possess a lower amount of phytotoxic micromycetes 
and a higher amount of diazotroph bacteria than in non-replant soil (Čatská, 1994), thereby optimizing the root and soil microflora diversity (Bharadwaj et al., 2008; Arturssonet et al., 2005). Moreover, diazotroph bacteria can produce more than antibiotics and phytohormones to resist replant disease. In addition, AM watermelon (Citrullus lanatus Thunb. 'Jingxin') plants enhanced the abundance of bacteria and actinomycetes and inhibit fungi under replant soil conditions (Zhao et al., 2010). Similar conclusions have been reached for apple under the condition of replant disease where mycorrhizal apple (Malus domestica Borkh 'Starking Delicious') seedlings increased the number of fungi, bacteria and actinomycetes in soils, resulting in better characteristics in the $\mathrm{pH}$ and nutrient levels of parasitic sites (Mehta and Bharat, 2013). Such AMF effects possibly provide the equilibrium between favorable and harmful microorganisms, and restore the original dynamic balance. AM-regulated soil and root microflora may be ascribed to alterations in root exudation of the host plant, competition for host resources and direct effects of mycorrhizal fungal exudates, individually or interactively (Vierheilig et al., 2003).

\section{Enhancement of enzyme activities in the soil and plants}

Soil enzyme activities can reflect the status of soil fertility and soil biological activity (Allison et al. 2007). Liu et al. (2011) found that AMF could secrete multiple soil enzymes, such as urease and phosphatase, eventually balancing the nutrients, $\mathrm{pH}$ and flora structure of replant soil. Zhang et al. (2015b) observed that inoculation with Funneliformis mosseae significantly increased the activity of catalase (CAT) and peroxidase (POD) in replant soils of peach (Prunus persica L. Batsch 'Great White') and decreased the activity of soil polyphenol oxidase (PPO), as compared with nonAMF inoculation. Among these enzymes, CAT is involved in soil detoxification of $\mathrm{H}_{2} \mathrm{O}_{2}$ accumulation (Huang et al., 2017; Liu et al., 2008). POD can eliminate soil allelochemicals and is associated with the synthesis of soil humus (Kong, 2007). PPO can oxidize soil substances, including amines and heterocyclic compounds (Wang et al., 2010). As a result, mycorrhizas strongly provide a greater soil microbial environment and soil fertility within the replant soil rhizosphere through better soil antioxidant enzyme activities in order to alleviate replant disease (Zhang et al., 2015b).
AM symbiosis can regulate activities of some hydrolytic enzymes in the soil to maintain balanced nutrient levels in the plant-soil system (Yang, 2014). As stated by Rutto and Mizutani (2006), the N content in leaves of peach (Prunus persica L. Batsch 'Ohatsumomo Batsch') was higher after inoculation with Gigaspora margarita and was due to the enhanced urease level under mycorrhization, resulting in intensive $\mathrm{N}$ decomposition and thus a decrease of $\mathrm{N}$ in the mycorrhizosphere. Similarly, $\mathrm{Hu}$ (2016) found that inoculation with Glomus mosseae significantly increased urease, acid phosphatase and sucrase activities under different levels of $\mathrm{p}$-hydroxybenzoic acid, leading to a better nutrient status in the host plant.

In addition to soil enzyme activities, AMF inoculation strongly stimulates plant antioxidant protective systems to enhance tolerance to replant disease in horticultural plants (Tab. 1). In grape (V. vulpina $\times V$. labrusca 'Beta') inoculation with Glomus mosseae, G. etunicatum and G. versiformis significantly enhanced leaf SOD activity under replant soil conditions, thereby inducing a lower membrane lipid peroxidation (lower MDA level) (Guo et al., 2009). Similarly, G. mosseae mycorrhizal strawberry (Fragaria $\times$ ananassa 'Sweet Charlie') exhibited greater activity of SOD, POD and CAT in leaves, as compared with non-mycorrhizal plants under replant soil conditions (Hu, 2016). Hence, AM plants grown in replant soil have higher antioxidant protective systems allowing them to tolerate replant disease.

\section{Changes in root exudates}

Studies found that AM plants excreted more isoflavones, glyceollin and coumestrol into the rhizosphere, with resistance to nematodes and pathogenic fungi under replant soil conditions (Tewoldemedhin et al., 2011). In the early stages of alfalfa (Medicago sativa L. 'Vernal') inoculated by mycorrhizal fungi, the concentration of several isoflavones in roots increased faster, including antitoxin and its prednisone and formononetin (Chon, 2006). This definitely reveals that the resistant products of plant secondary metabolism can to a certain degree be induced by mycorrhization to inhibit the infection, occurrence and development of pathogens. Root exudates, especially phenolic acids, terpenes and phytoalexins are closely related to disease resistance of plants (Yin et al., 2016). Also, the contents of secondary metabolites and the activities of antioxidant enzymes in roots are increased by 
mycorrhization (Wu et al., 2010) which is positively correlated with resistance to replant disease (Zhou et al., 2011). Furthermore, Hu (2016) analyzed the changes in allelochemicals of strawberry (Fragaria $\times$ ananassa 'Sweet Charlie'), and found that inoculation with Glomus mosseae could change the contents of root exudates, especially phenolic acid allelochemicals. Also, the allelopathic composition of strawberry rhizosphere soil identified by high performance liquid chromatography technology showed p-hydroxybenzoic acid, pilocarpine, vanillin, $\mathrm{p}$-coumaric acid, ferulic acid and benzoic acid. A study by Guo et al. (2009) showed that Glomus versiforme-inoculated mycorrhizal grape ( $V$. vulpina $\times$ V. labrusca 'Beta') released nerolidols in root exudates, but the non-AM control did not show nerolidol synthesis. On the other hand, root exudates also indirectly stimulate mycorrhizal associations impacting soil enzyme activities and the soil microbe population to change rhizospheric micro-environments (Paterson et al., 2007). As a result, changes in root exudates by mycorrhization can indirectly relieve replant disease in horticultural plants.

\section{Greater soil aggregate stability by glomalin- related soil proteins}

Glomalin that is released by spores and hyphae of AMF is defined in the soil as the glomalin-related soil protein (GRSP). GRSP is a major carbon source in the soil and can reflect the ecological status of the soil which is an indicator of soil fertility. GPRS can fix and disturb organic carbon in the soil, which provides a rich total carbon to increase plants biomass. Lovelock et al. (2004) demonstrated a significant positive correlation between organic carbon and GRSP contents. GPRS can be accumulated in the soil to improve its structure to be more suitable for plant growth (Rillig et al., 2002) because GPRS in many conditions, e.g., soil, sand, clay particles and organic matter, glues soil aggregates for better soil aggregate stability, in terms of the glycoprotein trait.

In peach (Prunus persica L. Batsch 'Great White'), inoculation with Funneliformis mosseae more significantly increased easily extractable GRSP and total GRSP concentration in the replant soil than non-AMF inoculation, irrespectively of whether the replant soil was autoclaved or not (Zhang et al., 2014, 2015b). Such increase of GRSP in replant soils heavily improved the soil aggregate stability in the size of 2-4 $\mathrm{mm}$ and $1-2 \mathrm{~mm}$ in autoclaved replant soil, but not in un-autoclaved replant soil (Fig. 1, Zhang et al., 2014, 2015b). Possibly replant soil generally exhibits negative effects on AMF colonization and subsequent GRSP production, thereby strongly altering the GRSP role in the aggregate stability of replant soil.

In addition to greater soil aggregate stability, GRSP can glue some toxic substances, including heavy metals, gallotannic acids, cyanogentic glycosides and hydrocyanic acids (Wu et al., 2014). GRSP can chelate some toxic substances in replant soil, thereby partly mitigating the degree of replant disease.

\section{Balanced nutrient levels in plants}

AMF can improve nutrient absorption in host plants, thereby alleviating the adverse effects of replant disease caused by the imbalance of mineral nutrients (Liu et al., 2011). AMF connects the root cells of host plants and enlarge the rhizospheric soil by hyphae, thereby, increasing the root surface area of absorption and indirectly easing the impact of growth disorders caused by replant disease through an infertile nutrient area within the root absorption range. Studies showed that the mycorrhizal apple (Malus domestica Borkh 'Topaz') possessed greater ability to uptake nutrients such as $\mathrm{P}, \mathrm{S}$, $\mathrm{Ca}, \mathrm{Mg}$ and $\mathrm{K}$ from soil (Gąstoł and DomagałaŚwiątkiewicz, 2015). Moreover, mycorrhizal roots also absorb more $\mathrm{N}$ and improve $\mathrm{N}$ utilization (Ren et al., 2016; Rutto and Mizutani, 2006). Mehta and Bharat (2013) demonstrated that mycorrhizal apple (Malus domestica Borkh 'Starking Delicious') seedlings had a higher level of $\mathrm{P}$ concentration in comparison with non-mycorrhizal plants which allowed mycorrhizal plants to tolerate soil-borne pathogens in replanted apple. The studies of Bharat and Bhardwaj (2001) and Raj and Sharma (2009) on apple (Malus domestica Borkh 'Red Delicious') in India found that apple seedlings infected by indigenous AMF enhanced immunity to pathogenic bacteria, resulting in a lower incidence of root rot. In addition, common mycorrhizal networks can transfer mineral nutrients and carbohydrates between neighboring plants, with the purpose of comprehensively improving the growth environment of the host plants (Zhang et al., 2015a).

Apart from plant nutrients, in replant soils, application of mycorrhizal fertilizer also significantly increases soil fertility for horticultural plants. For example, AMF application induced significantly higher available $\mathrm{K}, \mathrm{P}$ and $\mathrm{N}$ contents in 10 -year replant soil of pepper (Capsicum annuum L. 'Chinese Red') plants (Ren et al., 2016) which 


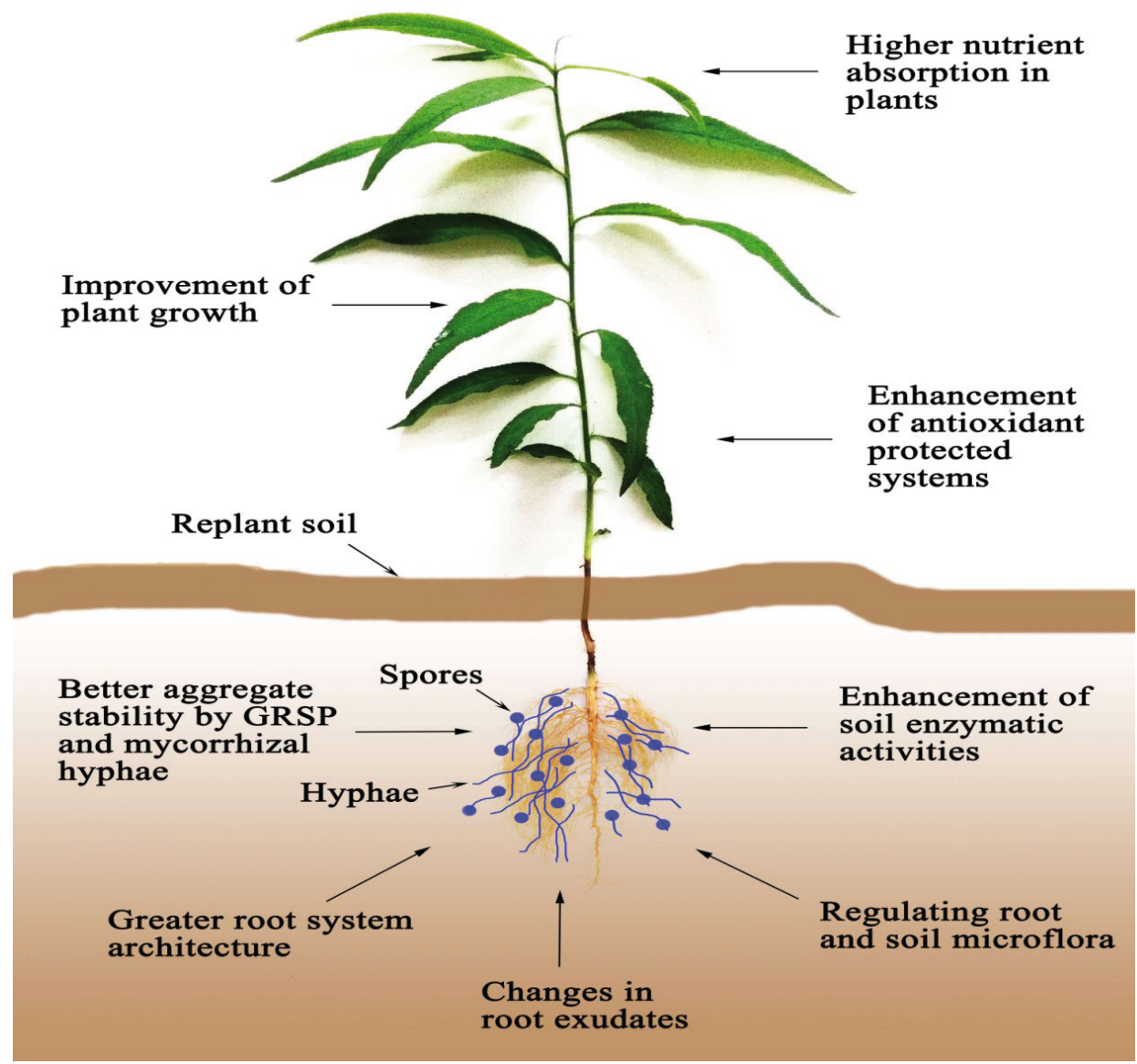

Figure 1. Underlying mechanisms of AMF on mitigating replant disease in horticultural plants

benefited the nutrient absorption of the host plants. However, a high P supply often reduces mycorrhizal colonization on host plants, resulting in an enhanced susceptibility of plants to pathogens (Mustafa et al., 2016). So, mycorrhizal application should be carefully considered in orchards.

\section{Greater root system architecture}

Root system architecture (RSA) refers as the spatial organization and arrangement of plant root systems in the soil, and plays a key role in controlling water and nutrient acquisition (Gérard et al., 2017). As reported by Zhang et al. (2014), replant soil heavily inhibited root development and the number of lateral roots in peach (Prunus persica L. 'Great White') seedlings. However, inoculation with Funneliformis mosseae strongly increased the root biomass and number of lateral roots in peach seedlings grown in unsterilized replant soil. In addition, significantly greater root length, root projected area, root surface area and root volume and thinner root diameter were also found in AMF peach seedlings than in nonAMF seedlings exposed to unsterilized replant soil (Tab. 2). Guo et al. (2009) also observed the greater root activity in AM grape ( . vulpina $\times V$. labrusca 'Beta') plants than non-AM control grown in replant

Table 2. Effects of an arbuscular mycorrhizal fungus (Funneliformis mosseae) on root morphological traits in peach seedlings grown in unsterilized replant soils

\begin{tabular}{lcccccc}
\hline $\begin{array}{l}\text { Replant } \\
\text { treatments }\end{array}$ & $\begin{array}{c}\text { AMF } \\
\text { treatments }\end{array}$ & $\begin{array}{c}\text { Root length } \\
(\mathrm{cm})\end{array}$ & $\begin{array}{c}\text { Root projected } \\
\text { area } \\
\left(\mathrm{cm}^{2}\right)\end{array}$ & $\begin{array}{c}\text { Root surface } \\
\text { area } \\
\left(\mathrm{cm}^{2}\right)\end{array}$ & $\begin{array}{c}\text { Root diameter } \\
(\mathrm{mm})\end{array}$ & $\begin{array}{c}\text { Root volume } \\
\left(\mathrm{cm}^{3}\right)\end{array}$ \\
\hline $\mathrm{NRP}$ & $+\mathrm{AMF}$ & $738 \pm 137 \mathrm{a}$ & $40.0 \pm 4.9 \mathrm{a}$ & $125.6 \pm 15.3 \mathrm{a}$ & $5.48 \pm 0.16 \mathrm{a}$ & $1.72 \pm 0.05 \mathrm{a}$ \\
& -AMF & $554 \pm 106 \mathrm{~b}$ & $27.8 \pm 3.3 \mathrm{~b}$ & $87.4 \pm 8.8 \mathrm{~b}$ & $5.01 \pm 0.32 \mathrm{ab}$ & $1.10 \pm 0.14 \mathrm{~b}$ \\
$\mathrm{RP}$ & $+\mathrm{AMF}$ & $587 \pm 67 \mathrm{ab}$ & $26.0 \pm 3.6 \mathrm{~b}$ & $81.8 \pm 11.3 \mathrm{~b}$ & $4.47 \pm 0.79 \mathrm{~b}$ & $1.03 \pm 0.07 \mathrm{~b}$ \\
& -AMF & $342 \pm 108 \mathrm{c}$ & $19.6 \pm 4.4 \mathrm{c}$ & $61.7 \pm 10.7 \mathrm{c}$ & $5.73 \pm 0.63 \mathrm{c}$ & $0.84 \pm 0.10 \mathrm{c}$ \\
\hline
\end{tabular}

Data (means $\pm \mathrm{SD}, \mathrm{n}=4$ ) followed by different letters indicate significant differences between treatments at $p<0.05$. Abbreviation: $+\mathrm{AMF}$, inoculation with Funneliformis mosseae; -AMF, inoculation without Funneliformis mosseae; NRP, non-replant; RP, replant 
soil. Such RSA changes by mycorrhization may be due to the allocation of glucose/sucrose to roots, the phytohormone modification and the regulation of endogenous polyamines, especially putrescine (Berta et al., 1993; Wu et al., 2011, 2012). As a result, greater RSA traits (e.g., length, area, volume, and activity) in replanted plants under mycorrhization will confer greater capacity to absorb water and nutrients from the soil and thus enhance stress tolerance, including the replant problem.

\section{FUTURE PERSPECTIVES}

The replant problem is a complex issue in horticultural plant production. Utilizing AMF as a microorganism agent has shown the potential value in mitigating soil replant disease. But, the mechanisms have been poorly studied, although glomalin, nutrients, root system architecture, antioxidant enzymes, root exudates and microflora balance were highlighted. There are still many issues that need to be clarified:

1. AMF can regulate the dynamic balance of the soil microflora to introduce or activate antagonistic bacteria for inhibition of pathogenic microorganisms. Thus, changes in soil microflora under mycorrhization need be further analyzed.

2. The changes in the components and concentrations of root exudates under mycorrhization need to be analyzed, and the potential components applied to test whether replant disease in horticultural plants can be mitigated.

3. Close attention should be paid to some metabolic pathways, such as salicylic acid and jasmonic acid (two key disease-resistant substances) which have not been studied. In addition, the processes of mycorrhiza-induced resistance in themselves remain elusive.

4. The RNA-seq technique should be used to screen high-efficiency up-regulated genes and metabolic pathways in plants and mycorrhizal fungi to understand the resistance to replant disease at molecular levels which is vital for the breeding of varieties resistant to replant disease.

5. More farmland studies for AMF application should be conducted to solve replant disease, because horticultural plants such as watermelon, pepper, eggplant, peach, apple and citrus are more mycorrhizal-dependent plants. Most earlier studies were conducted under controlled conditions and field experiments were scarce. More work needs to be moved from the lab to the field to confirm mycorrhizal roles in alleviating replant disease.

6. The potential capacity of various AMF species in mitigating replant diseas should be evaluated to screen highly efficient AM fungal strains in corresponding plants. In fact, the response of mycorrhizal inoculation in horticultural plants heavily depends on soil physical and chemical properties, plant species, inoculums, inoculation methods and other factors. As reported by Ridgway et al. (2008), a new species record in replant apple orchard in New Zealand, Scutellospora pellucida, was found. It provides the opportunity to determine whether the AMF strain is an effector in mitigating apple replant disease.

\section{FUNDING}

This study was supported by the Plan in Scientific and Technological Innovation Team of Outstanding Young Scientists, Hubei Provincial Department of Education (T201604).

\section{AUTHOR CONTRIBUTIONS}

L.H.L. - wrote the first manuscript (50\%); Q.S.W. - critically revised the manuscript for important intellectual content $(50 \%)$

\section{CONFLICT OF INTEREST}

Authors declare no conflict of interest.

\section{REFERENCES}

Akкöprü A., Demir S., 2005. Biological control of Fusarium wilt in tomato caused by Fusarium oxysporum f. sp. lycopersici by AMF Glomus intraradices and some rhizobacteria. J. Phytopathol. 153, 544-550.

ALDEA V., 1998. Role of microorganism in rhizosphere for determing a soil sickness in fruit culture. Acta Hortic. 477, 67-74.

Allison V.J., Condron L.M., Peltzer D.A., Richardson S.J., Turner B.L., 2007. Changes in enzyme activities and soil microbial community composition along carbon and nutrient gradients at the Franz Josef chronosequence. New Zeal. Soil Biol. Biochem. 39, 1770-1781.

Alvey S., Yang C.H., Buerkert A., Crowley D.E., 2003. Cereal/legume rotation effects on rhizosphere bacterial community structure in west african soils. Biol. Fertil. Soils 37(2), 73-82.

Artursson V., Finlay R.D., Jansson J.K., 2005. Combined bromodexyridine immunocapture and terminal-restriction fragment length polymorphism 
analysis highlights differences in the active soil bacterial metagenome due to Glomus mosseae inoculation or plant species. Environ. Microbiol. 7, 1952-1966.

Bais H.P., Weir T.L., Perry L.G., Gilroy S., Vivanco J.M., 2006. The role of root exudates in rhizosphere interactions with plants and other organisms. Ann. Rev. Plant Biol. 57, 233-266.

Baslam M., Garmendia I., Goicoechea N., 2011. Arbuscular mycorrhizal fungi (AMF) improved growth and nutritional quality of greenhouse-grown lettuce. J. Agric. Food Chem. 59, 5504-5515.

Benizri E., Piutti S., Verger S., Pagès L., Vercambre G., Poessel J.L., 2005. Replant diseases: bacterial community structure and diversity in peach rhizosphere as determined by metabolic and genetic fingerprinting. Soil Biol. Biochem. 37, 1738-1746.

Bent E., Loffredo A., Yang J., Mckenry M.V., Becker J.O., Borneman J., 2009. Investigations into peach seedling stunting caused by a replant soil. FEMS Microbiol. Ecol. 68, 192-200.

Berta G., Fusconi A., Trotta A., 1993. VA mycorrhizal infection and the morphology and function of root systems. Environ. Exp. Bot. 33, 159-173.

Bharadwaj D.P., Lundquist P.O., Alström S., 2008. Arbuscular mycorrhizal fungal spore-associated bacteria affect mycorrhizal colonization, plant growth and potato pathogens. Soil Biol. Biochem. 40, 24942501.

BRYK H., MiKicINSKI A., 2009. Antagonism of bacterial strains originated from soil towards some fungi causing orchard replant disease. Prog. Plant Prot. 49, 1497-1501.

Bharat N.K., BhardwaJ L.N., 2001. Interactions between VA-mycorrhizal fungi and Dematophora necatrix and their effect on health of apple seedlings. Ind. J. Plant Pathol. 19, 47-51.

Calvet C., Pinochet J., Hernández-Dorrego A., Estaún V., Camprubí A., 2001. Field microplot performance of the peach-almond hybrid GF-677 after inoculation with arbuscular mycorrhizal fungi in a replant soil infested with root-knot nematodes. Mycorrhiza 10, 295-300.

ČATSKÁ V., 1994. Interrelationships between vesiculararbuscular mycorrhiza and rhizosphere microflora in apple replant disease. Biol. Plant. 36, 99-104.

Cheng F., Cheng Z., 2016. Research progress on the use of plant allelopathy in agriculture and the physiological and ecological mechanisms of allelopathy. Front. Plant Sci. 6, 1020.

Chon S.U., 2006. Alfalfa (Medicago sativa L.) autotoxicity - replant problems. Korean J. Weed Sci. 26, 211-224.

Comby M., Mustafa G., Magnin-Robert M., Randoux B., Fontaine J., Reignault Ph., Lounes-Hadj Sahraoui A., 2017. Arbuscular mycorrhizal fungi as potential bioprotectants against aerial phytopathogens and pests. In: Arbuscular Mycorrhizas and Stress Tolerance of
Plants. Q.S. Wu (Ed.), Springer Nature Singapore Pte Ltd., Singapore, 195-223.

Duan F., Wang X.Y., GaO Z.H., 2011. Causes and control measures of continuous cropping obstacle in horticultural crops. Acta Agr. Jiangxi 23(3), 34-39 (in Chinese with English abstract).

Eayre C.G., Sims J.J., Ohr H.D., Mackey B., 2000. Evaluation of methyl iodide for control of peach replant disorder. Plant Dis. 84, 1177-1179.

FENG T.T., 2017. The effect of earthworm manure and straw biochar to control greenhouse continuous cropping cucumber. Master Dissertation. Yangzhou Univ., Jiangsu, China (in Chinese with English abstract).

Gąstol M., DomagaŁa-ŚwiątKiewicz I., 2015. Mycorrhizal inoculation of apple in replant soilsenhanced tree growth and mineral nutrient status. Acta Sci. Pol., Hortorum Cultus 14, 17-37.

Gérard F., Blitz-Frayret C., Hinsinger P., Pagès L., 2017. Modelling the interactions between root system architecture, root functions and reactive transport processes in soil. Plant Soil 413, 161-180.

Guo X.W., Li K., Guo Y.S., Zhang L.H., Sun Y.N., XIE H.G., 2009. Effect of arbuscular mycorrhizal fungi (AMF) strains on growth and root exudation characteristics of grapevine. J. Shenyang Agric. Univ. 40, 392-395 (in Chinese with English abstract).

Guo X.W., Li K., Xie H.G., Sun Y.N., Hu X.X., Zhang L.H., 2010. Effect of sterilized replant soil on grape growth and root exudation characteristics. J. Fruit Sci. 27: 29-33 (in Chinese with English abstract).

Hoagland R.E., Zablotowicz R.M., Oleszek W.A., 2001. Effects of alfalfa saponins on in vitro physiological activity of soil and rhizosphere bacteria. J. Crop Prod. 4, 349-361.

Hu J.L., Lin X.G., Wang J.H., Shen W.S., Wu S., Peng S.P., MaO T.T., 2010. Arbuscular mycorrhizal fungal inoculation enhances suppression of cucumber Fusarium wilt in greenhouse soils. Pedosphere 20, 586-593.

Hu X.P., 2016. Study on regulation of arbuscular mycorrhizal fungi in strawberry root allelopathic stress. Master Dissertation, Southwest Univ., Chongqing, China (in Chinese with English abstract).

Huang J.H., Liu J., Yang Z.L., Wei F., Guo C. Z. Jing F., et al., 2015. Changes of cotton straw incorporation on soil organic carbon activity matter of long-term continuous cropping cotton field. Ecol. Environ. Sci. 24, 387-395 (in Chinese with English abstract).

HuANG J.H., LuO S.M., ZENG R.S., 2003. Mechanisms of plant disease resistance induced by arbuscular mycorrhizal fungi. J. Appl. Ecol. 4, 819-822 (in Chinese with English abstract).

Huang Y., Jiao Y., Nawaz M.A., Chen C., Liu L., Lu Z., Kong Q., Cheng F., BIE Z., 2016. Improving magnesium uptake, photosynthesis and antioxidant enzyme activities of watermelon by grafting onto 
pumpkin rootstock under low magnesium. Plant Soil 409, 229-246.

HuANG Y.M., Zou Y.N., Wu Q.S., 2017. Alleviation of drought stress by mycorrhizas is related to increased root $\mathrm{H}_{2} \mathrm{O}_{2}$ efflux in trifoliate orange. Sci. Rep. 7, 42335.

Khan M.A., Chen J., LI Q., Zhang W., Wu L., Li Z., LIN W., 2014. Effect of interspecific root interaction on soil nutrition, enzymatic activity and rhizosphere biology in maize/peanut intercropping system. Pak. J. Agr. Sci. 51, 405-416.

Kong L.G., 2007. Studies on soil rhizosphere effect of continuous cropping poplar plantation. Master Dissertation, Shandong Agric. Univ., Tai'an, China (in Chinese with English abstract).

Li X., Lewis E.E., LiU Q., Li H., BAI C., WANG Y., 2016. Effects of long-term continuous cropping on soil nematode community and soil condition associated with replant problem in strawberry habitat. Sci. Rep. 6, 30466 .

LIN M., 2010. Studies on continuous cropping obstacle of Pseudostellaria heterophylla and its molecular ecological mechanism. Master Dissertation, Fujian Agr. For. Univ., Fuzhou, China (in Chinese with English abstract).

Liu J., Xie J.M., Chu Y.F., Sun C., Chen C., Wang Q., 2008. Combined effect of cypermethrin and copper on catalase activity in soil. J. Soil Sediment 8, 327-332.

LiU X.R., GE Q.P., Jie W.G., CAI B.Y., 2011. Research progress on AM fungi inhibited continuous cropping obstacle. J. Anhui Agric. Sci. 39, 21591-21593, 21646 (in Chinese with English abstract).

Lovelock C.E., Wright S.F., Clark D.A., Ruess R.W., 2004. Soil stocks of glomalin produced by arbuscular mycorrhizal fungi across a tropical rain forest landscape. J. Ecol. 92, 278-287.

Mamolos A.P., Kalburtui K.L., 2001. Significance of allelopathy in crop rotation. J. Crop Prod. 4, 197-218.

Marouelli W.A., Lage D.A.D.C., Gravina C.S., MicherefF Filho M., Souza R.B.D., 2013. Sprinkler and drip irrigation in the organic tomato for single crops and when intercropped with coriander. Rev. Cienc. Agron. 44, 825-833.

Maskina M.S., 1988. Response of wetland rice to fertilizer $\mathrm{N}$ in a soil amended with cattle, poultry and pig manures. Biol. Waste 26, 1-8.

Mehta P., Bharat N.K., 2013. Effect of indigenous arbuscular-mycorrhiza (Glomus spp.) on apple (Malus domestica) seedlings grown in replant disease soil. Ind. J. Agric. Sci. 83, 1173-1178.

Moose S.P., Mumm R.H., 2008. Molecular plant breeding as the foundation for 21 st century crop improvement. Plant Physiol. 147, 969.

Mustafa G., Randoux B., Tisserant B., Fontaine J., Magnin-Robert M., Lounes-Hadj Sahraoui A., Reignault P.H., 2016. Phosphorus supply, arbuscular mycorrhizal fungal sepceis, and plant genotype impact on the protective efficacy of mycorrhizal inoculation against wheat powdery mildew. Mycorrhiza 26, 685697.

NadeEm S.M., Khan M.Y., Waqas M.R., Binyamin R., AKHTAR S., ZAHIR Z.A., 2017. Arbuscular mycorrhizas: An overview. In: Arbuscular Mycorrhizas and Stress Tolerance of Plants. Q.S. Wu (Ed.), Springer Nature Singapore Pte Ltd., Singapore, 1-24.

Nanjappa H.V., SOUmya T.M., Ramachandrappa B.K., PrabHaKara B.N., 2008. Productivity and economics of transparent polyethylene for soil solarization in groundnut (Arachis hypogaea) - bell pepper (Capsicum annum) sequence. Ind. J. Agron. 53,125128.

OGWENo J.O., Yu J.Q., 2006. Autotoxic potential in soil sickness are examination. Allelopathy J. 18, 93-101.

Ortas I., 2012. Mycorrhiza in Citrus: Growth and Nutrition. In: Advances in Citrus Nutrition. A.K. Srivastava (Ed.), Springer, Netherlands, 333-351.

Ortas I., RafiQue M., Ahmed I.A.M., 2017. Application of arbuscular mycorrhizal fungi into agriculture. In: Arbuscular Mycorrhizas and Stress Tolerance of Plants. Q.S. Wu (Ed.), Springer Nature Singapore Pte Ltd., Singapore, 305-327.

Paterson E., Gebbing T., Abel C., Sim A., Telfer G., 2007. Rhizodeposition shapes rhizosphere microbial community structure in organic soil. New Phytol. 173, 600-610.

Qi G.H., Chen G.L., Lü G.Y., Nie L.C., Ding P.H., 2001. Effects of arbuscular mycorrhizal fungi on the yield and quality of strawberry grown in replanted soil. J. Fruit Sci. 18, 341-344 (in Chinese with English abstract).

Qi G.H., ZHANG L.P., YANG W.L., Lu X.R., Li C.L., 2002. Effects of arbuscular mycorrhizal fungi on growth and disease resistance of replanted ginkgo (Ginkgo biloba L.) seedlings. Hebei J. For. Orch. Res. 17, 58-61 (in Chinese with English abstract).

Raj H., Sharma S.D., 2009. Investigation on soil solarization and chemical sterilization with beneficial microorganisms for control of white root rot and growth of nursery apple. Sci. Hortic. 119, 126-131.

Ren L., Zhang N., Wu P., Huo H., Xu G., Wu G., 2015. Arbuscular mycorrhizal colonization alleviates Fusarium wilt in watermelon and modulates the composition of root exudates. Plant Growth Regul. 77, 77-85.

Ren X.Q., Pan G.Q., Chen B.Q., Zhang Y.P., Peng L., XU X., YANG W. 2016. Effects of arbuscular mycorrhizal fungus (AMF) on soil nutrients and enzyme activities in continuous cropping greenhouse of Huai'an red pepper. Hubei Agric. Sci. 55, 4565 4568 (in Chinese with English abstract).

Ridgway H.J., Kandula J., Stewart A., 2008. Arbuscular mycorrhiza improve apple rootstock growth in soil conducive to specific apple replant disease. New Zeal. Plant Prot. 61, 48-53.

Rillig M.C., Aguilar-Trigueros C.A., Bergmann J., Verbruggen E., Veresoglou S.D., Lehmann A., 
2015. Plant root and mycorrhizal fungal traits for understanding soil aggregation. New Phytol. 205, 1385-1388.

Rillig M.C., Wright, S.F., Eviner, V.T., 2002. The role of arbuscular mycorrhizal fungi and glomalin in soil aggregation: Comparing effects of five plant species. Plant Soil 238, 325-333.

Roy-Bolduc A., HiJRi M., 2012. The use of mycorrhizae to enhance phosphorus uptake: A way out the phosphorus crisis. J. Biofertil. Biopestic. 2, 104.

Rumberger A., Merwin I.A., Thies J.E., 2007. Microbial community development in the rhizosphere of apple trees at a replant disease site. Soil Biol. Biochem. 39, 1645-1654.

Rutto K.L., Mizutani F., 2005. Replant soil and peach detritus inhibit arbuscular mycorrhizal activity and retard peach seedlings growth. Bull. Exp. Farm Fac. Agr. Ehime Univ. 27, 1-9.

Rutto K.L., Mizutani F., 2006. Peach seedling growth in replant and non-replant soils after inoculation with arbuscular mycorrhizal fungi. Soil Biol. Biochem. 38, 2536-2542.

Sewell G.W.F., Preece D.A., Elsey R.F., 2010. Apple replant disease: the influence of soil phosphorus and other factors on the growth responses of apple seedlings to soil fumigation with chloropicrin. Ann. Appl. Biol. 113, 605-615.

Sheng J.M., WU X.Q., 2007. Interaction between mycorrhizal fungi and rhizosphere microorganisms. J. Northwest For. Univ. 22(5),104-108 (in Chinese with English abstract).

Sieverding E., LeIHner D.E., 1984. Influence of crop rotation and intercropping of cassava with legumes on VA mycorrhizal symbiosis of cassava. Plant Soil 80, 143-146.

Sun X.T., Long G.H., Zhang G.Z., Chen Z.J., Yang S.C., Chen J.W., 2015a. Properties of soil physicalchemistry and activities of soil enzymes in context of continuous cropping obstacles for Panax notoginseng. Ecol. Environ. Sci. 24, 409-417 (in Chinese with English abstract).

Sun X.T., Li L., Long G.Q., Zhang G.H., Meng Z.H., YAng S.C., Chen J.W., 2015b. The progress and prospect on consecutive monoculture problems of Panax notoginseng. Chin. J. Ecol. 34, 885-893 (in Chinese with English abstract).

Tewoldemedhin Y.T., Mazzola M., Labuschagne I., MCLeOd A., 2011. A multi-phasic approach reveals that apple replant disease is caused by multiple biological agents, with some agents acting synergistically. Soil Biol. Biochem. 43, 1917-1927.

UtKHEDE R.S., 2006. Soil sickness, replant problem or replant disease and its integrated control. Allelopathy J. 18, 23-38.

Vierheilig H., Lerat S., Piché Y., 2003. Systemic inhibition of arbuscular mycorrhiza development by root exudates of cucumber plants colonized by Glomus mosseae. Mycorrhiza 13, 167-170.
Wang C.B., Wu Z.F., Cheng B., Zhang Y.P., WaN S.B., Guo F., CHEN D.X., 2007. Effect of continuous cropping on photosynthesis and metabolism of reactive oxygen in peanut. Acta Agron. Sin. 33(8), 1304-1309 (in Chinese with English abstract).

Wang C.X., Li X.L., Song F.Q., 2012. Protecting cucumber from fusarium wilt with arbuscular mycorrhizal fungi. Commun. Soil Sci. Plant Anal. 43, 2851-2864.

WANG S., Wu Q.S., HE X.H., 2015. Exogenous easily extractable glomalin-related soil protein promotes soil aggregation, relevant soil enzyme activities and plant growth in trifoliate orange. Plant Soil Environ. 61, 66-71.

WANG W., ZHU X., LiU W., 1998. Influence of ragweed (Ambrosia trifida) on plant parasitic nematodes. J. Chem. Ecol. 24, 1707-1714 (in Chinese with English abstract).

WANG Z.G., XU W.H., Guo T.W., 2010. Effects of Chinese chives' continuous cropping on microbial quantity and enzymes activities in the soil of big cote. Chin. J. Soil Sci. 41, 1048-1052 (in Chinese with English abstract).

Waschkies C., Schropp A., Marschner H., 1994. Relations between grapevine replant disease and root colonization of grapevine (Vitis sp.) by fluorescent pseudomonads and endomycorrhizal fungi. Plant Soil 162, 219-227.

Wei X.C., Yang J.M., LiaO K.Z., Shi M.W., Ma X.L., JIANG F., 2009. Reasons for continuous operation obstacle and comprehensive prevention measures. Shanghai Vegetables (2), 61-62 (in Chinese with English abstract).

Wilson S., ANDrEws P., NAIR T.S., 2004. Non-fumigant management of apple replant disease. Sci. Hortic. 102, 221-231.

Wu F.Z., LiU B., ZHou X.A., 2010. Effects of root exudates of watermelon cultivars differing in resistance to Fusarium wilt on the growth and development of Fusarium oxysporum f. sp. niveum. Allelopathy J. 25, 403-414.

Wu H.S., Yang X.N., Fan J.Q., Miao W.G., Ling N., Xu Y.C., Huang Q.W., Shen Q., 2009. Suppression of Fusarium wilt of watermelon by a bio-organic fertilizer containing combinations of antagonistic microorganisms. Biocontrol 54, 287.

Wu Q.S., CaO M.Q., Zou Y.N., He X.H., 2014. Direct and indirect effects of glomalin, mycorrhizal hyphae, and roots on aggregate stability in rhizosphere of trifoliate orange. Sci. Rep. 4, 5823.

Wu Q.S., He X.H., Zou Y.N., Liu C.Y., XiaO J., Li Y., 2012. Arbuscular mycorrhizas alter root system architecture of Citrus tangerine through regulating metabolism of endogenous polyamines. Plant Growth Regul. 68, 27-35.

Wu Q.S., Li G.H., Zou Y.N., 2011. Improvement of root system architecture in peach (Prunus persica) seedlings by arbuscular mycorrhizal fungi, related to 
allocation of glucose/sucrose to root. Not. Bot. Horti. Agrobot. Cluj Napoca 39, 232-236.

Wu Q.S., Srivastava A.K., Zou Y.N., 2013. AMF-induced tolerance to drought stress in citrus: A review. Sci. Hortic. 164, 77-87.

Wu Q.S., XIA R.X., Zou Y.N., 2008. Improved soil structure and citrus growth after inoculation with three arbuscular mycorrhizal fungi under drought stress. Eur. J. Soil Biol. 44, 122-128.

XIE H.G., Li K., 2008. Mechanism and ways of control on replant diseases of fruit trees. J. Liaoning Agr. Coll. 10, 7-8 (in Chinese with English abstract).

YANG C., Jing Y., WANG Y., CAI W., JiA Z., 2015. Rhizospheric denitrification potential and related microbial characteristics affected by secondary salinization in a riparian soil. Geomicrobiol. J. 32, 624-634.

YANG H.Y., 2014. Effects of arbuscular mycorrhizal fungi on peach seedlings growth in replant soil. Master Dissertation, Huazhong Agric. Univ., Wuhan, China (in Chinese with English abstract).

Yang J.I., Ruegger P.M., Mckenry M.V., Becker J.O., Borneman J., 2012. Correlations between rootassociated microorganisms and peach replant disease symptoms in a California soil. PLoS ONE 7, e46420.

Yao S., Merwin I.A., Abawi G.S., Thies J.E., 2006. Soil fumigation and compost amendment alter soil microbial community composition but do not improve tree growth or yield in an apple replant site. Soil Biol. Biochem. 38, 587-599.

Yin C., Li X., Wang G., Wang Y., Shen X., Chen X., Mao Z., 2016. How to plant apple trees to reduce replant disease in apple orchard: a study on the phenolic acid of the replanted apple orchard. PLoS ONE 11, e0167347.

Yu J.Q., Matsui Y., 1994. Phytotoxic substances in root exudates of cucumber (Cucumis sativus L.). J. Chem. Ecol. 20, 21-31.

YU J.Q., 2011. Progress in protected vegetable production and research during 'the elevevth five-year plan' in China. China Vegetables (2),11-23 (in Chinese with English abstract).

Zhang Z.Z., Lou Y.G., Deng D.J., Rahman M.M., Wu Q.S., 2015a. Effects of common mycorrhizal network on plant carbohydrates and soil properties in trifoliate orange-white clover association. PLoS ONE 10, e0142371.
Zhang Z.Z., Srivastava A.K., Wu Q.S., Li G.H., 2015 b. Growth performance and rhizospheric traits of peach (Prunus persica) in response to mycorrhization on replant versus non-replant soil. Ind. J. Agr. Sci. 85, 125-130.

ZHANG Z.Z., Wu Q.S., Li G.H., 2014. Effects of arbuscular mycorrhizal fungi on growth and rhizospheric soil structure of Prunus persica. South Chin. Fruits 43, 14-17 (in Chinese with English abstract).

ZHAO D.K., 2011. Effects of arbuscular mycorrhiza on watermelon fusarium wilt in aerobic rice and watermelon intercropping. Master Dissertation, Nanjing Agr. Univ., Nanjing, China (in Chinese with English abstract).

ZhaO M., Li M., LiU R.J., 2010. Effects of arbuscular mycorrhizae on microbial population and enzyme activity in replant soil used for watermelon production. Int. J. Eng. Sci. Technol. 2, 17-22.

Zhao X., Zhen W., Qi Y., LiU X., Yin B., 2009. Coordinated effects of root autotoxic substances and Fusarium oxysporum Schl. f. sp. fragariae on the growth and replant disease of strawberry. Front. Agric. China 3, 34.

ZHeN W., CAO K., DAI L., Zhang X., 2004. Simulation of autotoxicity of strawberry root exudates under continuous cropping. Acta Phytoecol. Sin. 28, 828-832 (in Chinese with English abstract).

ZHU Y., Fox R.H., 2003. Corn-soybean rotation effects on nitrate leaching. Agron. J. 95, 1028-1033.

Zhou B.L., Chen Z.X., Du L., XIE Y.H., Zhang Q., Ye X.L., 2011. Allelopathy of root exudates from different resistant eggplants to Verticillium dahliae and the identification of allelochemicals. Afr. J. Biotechnol. 10, 8284-8290.

ZHOU H., YANG Z., Li H., GUAN C., 2004. Effect of straw return to field and fertilization in autumn on dryland corn growth and on water and fertilizer efficiency. J. Appl. Ecol. 15, 1231-1235 (in Chinese with English abstract).

Zou Y.N., Srivastava A.K., Wu, Q.S., Huang, Y.M., 2014. Glomalin-related soil protein and water relations in mycorrhizal citrus (Citrus tangerina) during soil water deficit. Arch. Agron. Soil Sci. 60, 1103-1114.

Received September 2, 2017; accepted February 16, 2018 